\title{
THE STUDY OF SOVIET AND POST-SOVIET STATEHOOD AS A SINGLE HISTORICAL PROCESS BOOK REVIEW: «SOVIET AND POST-SOVIET STATE AND LAW (COMPARATIVE LEGAL STUDY)» BY M.N. MARCHENKO (MOSCOW: PROSPEKT PUBL., 2017)
}

\author{
Anisim I. Ekimov \\ Peoples' Friendship University of Russia (RUDN University) \\ Law Institute \\ 6, Miklukho-Maklaya st., Moscow, Russia, 117198
}

The large scale analysis of the Soviet and post-Soviet periods of development of the national statehood is given in the new book of the famous Russian lawyer, Prof. M.N. Marchenko. The Soviet past is usually viewed as an era of the greatest achievements of the Russian people and as a time of terrible crimes committed against it. However, the post-Soviet period does not obtain perfection. The research methodology used by the author excludes a leaning in the analysis of Soviet and postSoviet statehood. With some stages in the development of Russia appear to be only evil, and others, on the contrary, are being praised without any measure. Prof. M.N. Marchenko considers any attempts to expose destructive criticism of both periods, in the development of our state and law, are ineffective.

Using the comparative method of research combined with dialectical and historical approaches, the scientist comes to an important conclusion for the Russian legal science that the Soviet and post-Soviet statehoods are not heterogeneous but homogeneous phenomena. It is emphasized what is common between them prevails in relation to the particular, constitutes the national «root base», the foundation of the Soviet and post-Soviet states. This is predetermined by the fact that they arose on the basis of the same national and cultural society - the Russian society. Furthermore, they arose in the historical framework of the Russian state. Passing through the drastically different stages of development in its history, the Russian state solely never ceases to stand by its original nature, the culture of its people, its historical traditions and folk customs. In each type of state that arisen on the basis of Russian society, genetically incorporated generic features and traits familiar to the Russian state as a phenomenon in general. 
Outlining these positions, the author believes that it is possible and necessary to speak about continuity between the Soviet and post-Soviet states. Until recent times such a judgment could be considered unpleasant, a desire not to recognize the greatness of the changes that took place in 1917, then in 1991-1993. A comprehensive justification of the idea of continuity between phenomena was the scientist's undoubted merit, but in the closest past it was considered mutually exclusive by many scientists.

The state and law in Russia - the Soviet and post-Soviet - are viewed from the standpoint of diachronic analysis, that is, the chronological sequence of their appearance and development. Therefore, a lot of fundamentally important observations were made. Thus, the author writes the nature of the state and law are not disclosed at once, but rather intermittently, subject to the peculiarities of the place and time. Like any social organism, the state and law have periods of not only ups, rapid development, but also protracted recessions. It follows that one should not make far-reaching conclusions about the essence of the state and law, based only on occasional events that are not conditioned by profound social factors. Diachronic comparative analysis reveals the unfolding of the essence of the Soviet and post-Soviet state and law. However, it is not fully used in the work. The post-Soviet state has existed for more than a quarter of a century. The question arises: what did the Soviet and post-Soviet states achieve in comparable periods of time? In this case, it should be born in mind that they started their history from different initial points of reference. The Soviet state arose as a result of severe shocks caused by the World War I and civil war. The postSoviet state eventually became the heir of one of the two superpowers, whose influence extended to the whole world. A comparative analysis of the dynamics of the essence of each of these states undoubtedly has not only a scientific but also a practical meaning.

The book examines the state legal doctrines of the Soviet and post-Soviet periods. It is rightly noted that the Marxist-Leninist doctrine of the state and law practically was not realized in any of the countries (p. 145). The surrogates and pseudoMarxist institutions were created instead of a socialist state and law. But the discrepancy between the state legal theory and the practice of its implementation, as the author believes, does not give grounds for generalizing and drawing conclusions about the general inadequacy of this theory and the inconsistency of all state-legal practice; the failures of socialism were connected not with the idea of socialism, but with its realization (p. 153).

Theories of the post-Soviet state are considered in the monograph as theories of the transition from socialism to capitalism. They fill the deficit of strategically important concepts that emerged in post-Soviet Russia, and in this respect, as the author rightly points out, have a positive role. At the same time, he very critically assesses the theory of the legal state in its Russian version, opposes its idealization (p. 139). His position coincides with the estimates of a number of Western political scientists (F. Fukuyama and others). The point of separation of powers, according to the scientist, is only that it does not concentrate in the hands of one person or a group of peo- 
ple (p. 183). In reality, the balance between the authorities is constantly changing. Perhaps, the author should dwell in detail on this issue, in order to more clearly decipher the "secret" mechanisms of democracy. Usually, as the weakest link in the theory of separation of powers, they point to the place in it of the organs of justice, which, in the event of an acute conflict with other branches of power, may prove powerless. Furthermore, the problem of ensuring a balance between the executive and legislative powers still remains. In 2017, the whole world watched as the resources of the presidential power depleted under the influence of the Congress in the United States. There was not necessary to revise the constitutional provisions, so that the power in the country had been changed noticeably. It was mainly due to subjective factors: the intentions and abilities of people in power. The study of the noted «weak spot» in the theory of separation of powers is also a task for the future. There is a very important observation of Prof. M.N. Marchenko regarding the institution of separation of powers: its existence does not mean existence of democracy (p. 141). Of course, it is true. However, without the separation of powers, things can go even worse.

The author's views on the relationship between a legal state (Rechtsstaat) and a civil society appear to be exceptionally significant arguing as follows. The state grew out of society, was brought to life by society and conditioned by its nature. A legal state is constructed exactly the same, but on the basis of a civil society, which precedes it. It is the condition of civil society that determines what a legal state is, not the other way around. This does not mean that a state takes the passive position of an outside observer on a civil society. A state is always present in a civil society, it is active, but does not play a "decisive role" (p. 224).

The book pays particular attention to the identification and consideration of trends in the development of post-Soviet Russia, its strengths and weaknesses. It is emphasized that some of the factors that led to the death of the Soviet state are also being manifested at the present time. These include, in particular, the conflicting views and aspirations of the ruling elite, the lack of political responsibility of the authorities for failures of its politics, and nationalist, separatist and extremist manifestations. The scientist is sure Russia will not be able to solve its problems without a strong state, without the consistent implementation of the political course aimed at the development of a self-sufficient economy, and the strengthening of the state's defensive capability (p. 310).

Prof. M.N. Marchenko clearly demonstrates the possibility of chosen methodological approach, turning to the issue of the Russian state and law future. He stresses that evolutionary or revolutionary conditions and prerequisites for the transition to the next stage takes shape at each stage of Russian society and state development. Thus, objective prerequisites for the transition to the Soviet period appeared in the preOctober period (1917). During the Soviet period, the ruling elite created predominantly subjective conditions for the transition to a liberal post-Soviet system. As shown in the book, copying Western models by post-Soviet Russia did not lead to the expected success. Therefore, in the future it seems «quite natural» (p. 43) to see a transition 
from the post-Soviet stage of the Russian state and law development to the next stage, modelled on early or late capitalism or social democracy. Apparently, it is worth to listen to this forecast.

In the book, the analysis of the relations between the Soviet and post-Soviet legal systems plays an important role. Prof. M.N. Marchenko found there were similarities between several levels: the level of legal sources, the general principles of the formation and functioning of legal systems, the level of their internal composition (structure and institutional content) and, finally, the level of their theoretical perception and comprehension as homogeneous and one-order legal phenomena. In other words, the Soviet legal system is in many ways «native» to the post-Soviet system. The author concludes with making a comparison of certain elements of the Soviet and post-Soviet legal systems.

Of course, the monograph does not cover all the problems related to the research topic, such as the state of law and order, bureaucracy of the state apparatus, the principles of its formation and functioning, the relationship between the state and the church, legal axioms, etc. Apparently, the greater effectiveness of the study could be achieved by using the method of mentality, rooted in Western historiography, which is characterized by the de-ideologization of knowledge, the search for ideas and concepts that powerfully determine the human mind and behavior but lay "below" the dominant ideological systems. In this case, analysis and understanding of the state and law are dramatically transformed into what is commonly called part of the everyday way of people's life.

It is difficult to agree with certain opinions of the author, in particular, with the interpretation of the events in 1991-1993 as a military takeover, and not a political revolution or at least a counter-revolution. He believes that the events of the 1990s cannot be called a revolution, since they were prepared in the struggle, not between classes, but between different groups of the same social strata or class (p. 70). This idea does not stand up to criticism. In fact, it is known that it was the hidden struggle of classes under the flag of the struggle between different strata of society that was hidden from the people, as evidenced by the subsequent antisocialist transition.

Attention should be given to the controversial provisions of the work. I suppose that the author is too reserved about the idea of convergence as a possible direction for the development of the post-Soviet state. It was proposed by Western ideologists, in under relaxation of international tension, and was aimed at combining the advantages of capitalism and socialism within a single political and economic system. In the USSR, it was immediately declared a hostile ideological action. Now that Russia has turned away from its socialist past, the convergence theory causes superstitious fear for those who see it as an excuse for the past political practice of the USSR. It should be remembered, that academician E.M. Primakov was extremely positive about convergence throughout his career, he thought it was "a straight path for development of all humankind". 
To summarize, the book by prof. M.N. Marchenko makes a significant contribution to the formation of such a new scientific direction in national legal science as a comparative study of the past and the present in the dynamics of the state and law.

\title{
Information about the Author
}

Anisim I. Ekimov, Honoured Lawyer of the Russian Federation, Honoured Worker of Higher Education of the Russian Federation, Doctor of Law, Professor, Department of Theory of Law and State, Institute of Law, Peoples' Friendship University of Russia (RUDN University)

ORCID ID: 0000-0002-6463-6820

Contact information:

e-mail:rospravo@mail.ru

\section{For citation:}

Ekimov, A.I. (2018). The Study of Soviet and Post-Soviet Statehood as a Single Historical Process. Book review: "Soviet and Post-Soviet State and Law (Comparative Legal Study)" by M.N. Marchenko (Moscow: Prospekt Publ., 2017). RUDN Journal of Law, 22 (2), pp. 307-313. doi: 10.22363/2313-2337-2018-22-2-307-313.

Article received March 13, 2018

Article accepted April 15, 2018

\section{ИССЛЕДОВАНИЕ СОВЕТСКОЙ \\ И ПОСТСОВЕТСКОЙ ГОСУДАРСТВЕННОСТИ \\ КАК ЕДИНОГО ИСТОРИЧЕСКОГО ПРОЦЕССА \\ О КНИГЕ М.Н. МАРЧЕНКО «СОВЕТСКОЕ И \\ ПОСТСОВЕТСКОЕ ГОСУДАРСТВО И ПРАВО \\ (СРАВНИТЕЛЬНО-ПРАВОВОЕ ИССЛЕДОВАНИЕ)» \\ (МОСКВА: ПРОСПЕКТ, 2017 г.)}

\author{
А.И. Экимов \\ Российский университет дружбы народов \\ Юридический институт \\ 117198, Москва, Россия, ул. Миклухо-Маклая, 6
}

В новой книге известного российского юриста, профессора М.Н. Марченко дается масштабный анализ советского и постсоветского периодов развития отечественной государственности. Советское прошлое обычно о рассматривают и как эпоху величайших достижений нашего народа, и как время чудовищных преступлений против него. Не стал идеальным и постсоветский период. Автор 
использует методологию исследования, которая исключает конъюнктурность в анализе советской и постсоветской государственности, когда одни этапы в развитии нашей страны представляются только злом, а другие, напротив восхваляются без всякой меры. Попытки подвергать уничтожающей критике тот или иной период в развитии нашего государства и права он считает контрпродуктивными.

Используя сравнительный метод исследования, соединенный с диалектическим и историческим подходами, ученый приходит к важному для нашей юридической науки выводу, что советская и постсоветская государственность это не разнородные, а однородные феномены. Общее между ними, подчеркивается в книге, преобладает по отношению к особенному, составляет национальную «корневую основу», фундамент советского и постсоветского государства. Это предопределено тем, что они возникли на базе одного и того же национального и культурного социума - российского общества и в исторических рамках одного и того же, в конечном счете, российского государства. Проходя в своей истории кардинально различающиеся между собой этапы развития, российское государство никогда не перестает быть по своей изначальной природе, культуре народа, историческим традициям и народным обычаям именно российским, а не каким-либо иным государством. В каждом возникшем на базе российского общества типе государства генетически заложены общеродовые признаки и черты, свойственные именно российскому государству как явлению в целом.

Излагая эти позиции, автор считает, что можно и должно говорить о преемственности между советским и постсоветским государством. Всестороннее обоснование идеи преемственности между явлениями, которые еще недавно многими в нашей науке считались взаимоисключающими, - несомненная заслуга ученого.

\section{Сведения об авторе}

Экимов Анисим Иванович, Заслуженный юрист РФ, Почетный работник высшего профессионального образования РФ, доктор юридических наук, профессор, кафедра теории государства и права, юридический институт, Российский университет дружбы народов

\section{ORCID ID: 0000-0002-6463-6820}

Контактная информация:

e-mail: rospravo@mail.ru

\section{Для цитирования:}

Экимов А.И. Исследование советской и постсоветской государственности как единого исторического процесса. О книге: М.Н. Марченко «Советское и 
постсоветское государство и право (сравнительно-правовое исследование)» (Москва: Проспект, 2017 г.) // Вестник Российского университета дружбы народов. Серия: Юридические науки. 2018. Т. 22. № 2. С. 307-313. doi: 10.22363/2313-2337-2018-22-2-307-313.

Дата поступления в редакцию: 13 марта 2018 г. Дата принятия к печати: 15 апреля 2018 г. 